\title{
Key Plant, Key Pests: Chinese Elm (Ulmus parvifolia) ${ }^{1}$
}

Juanita Popenoe, Caroline R. Warwick, and Richard Beeson Jr. ${ }^{2}$

\section{Key Plant: Chinese Elm (Ulmus parvifolia)}

Chinese elm (Ulmus parvifolia) are fast-growing evergreen trees that are well-suited for use in landscapes. They often grow to a height of 40 to 50 feet, forming an upright, rounded canopy of long branches, making them ideal for use in parking lots or along streets. In addition to being found throughout Florida, they can be found throughout most of the United States in USDA hardiness zones 5B through 10A. Chinese elms do best in well-drained, occasionally wet, acidic soils and can tolerate partial shade, partial sun, or full sun light levels. They are extremely drought-tolerant and are thought to be under-utilized in Florida landscapes (Gilman and Watson 2014).

\section{Key Pests: Chinese Elm}

This series of Key Plant, Key Pests publications are designed for Florida gardeners, horticulturalists, and landscape professionals to help identify common pests associated with plants commonly found in Florida landscapes. This publication, the third in the Key Plant, Key Pests series, helps identify the most common pests found on the Chinese elm (Ulmus parvifolia).

This publication provides information and general management recommendations for anthracnose (or black elm spot), powdery mildew, trunk canker, wood-boring pests, eriophyid mites, and leaf beetles. For a more comprehensive guide of woody ornamental insect management, download

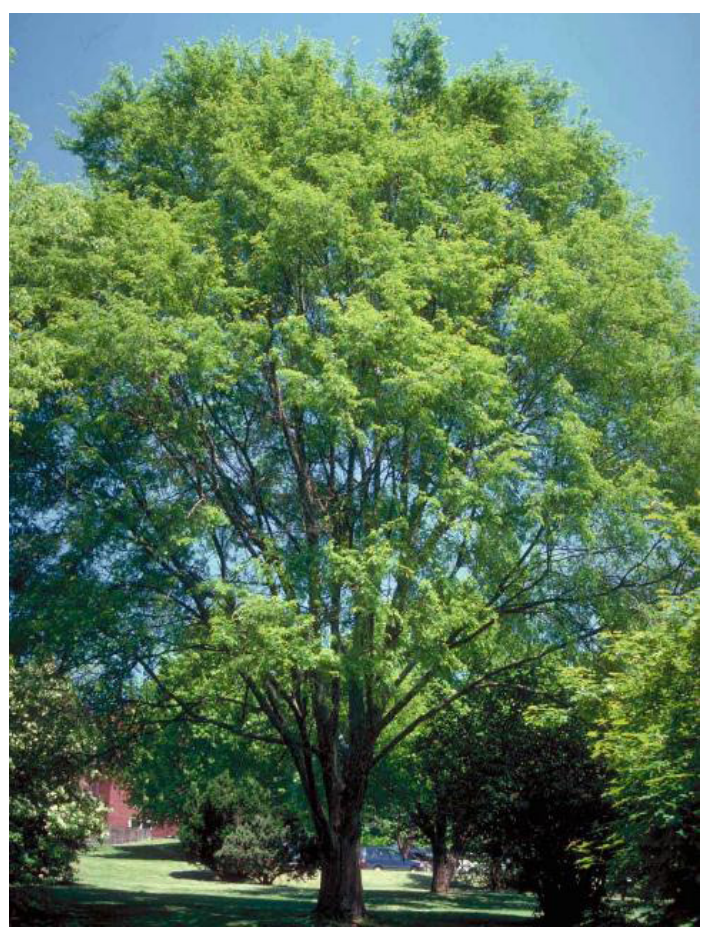

Figure 1. A middle-aged Chinese elm. Credits: Ed Gilman, UF/IFAS

the current Professional Disease Management Guide for Ornamental Plants or the Integrated Pest Management in the Commercial Ornamental Nursery Guide. For specific pesticide recommendations, please refer to the 2017 southeastern US Pest Control Guide for Nursery Crops and Landscape Plantings (https://adamgdale.files.wordpress. com/2016/08/2017_ornamental_pest-control-guide.pdf).

1. This document is ENH1295, one of a series of the Environmental Horticulture Department, UF/IFAS Extension. Original publication date July 2018. Visit the EDIS website at http://edis.ifas.ufl.edu.

2. Juanita Popenoe, multi-county commercial fruit production agent IV; Caroline Roper Warwick, science communication specialist; and Richard Beeson Jr., associate professor; UF/IFAS Extension, Mid-Florida Research and Education Center, Apopka, FL 32703.

The Institute of Food and Agricultural Sciences (IFAS) is an Equal Opportunity Institution authorized to provide research, educational information and other services

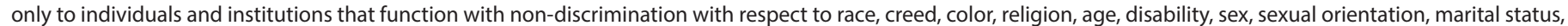

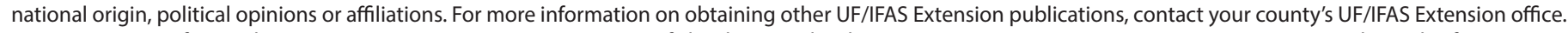
U.S. Department of Agriculture, UF/IFAS Extension Service, University of Florida, IFAS, Florida A \& M University Cooperative Extension Program, and Boards of County Commissioners Cooperating. Nick T. Place, dean for UF/IFAS Extension. 


\section{Anthracnose or Black Elm Spot (Stegophora ulmea)}

Recognition: Small yellow spots initially develop on the upper surface of leaves in spring, and may expand to entire leaves and petioles, girdling shoot growth. Fungus appears on the leaves as small, black structures with black spines extending from a cushion-like center. Repeated infections in early summer result in premature defoliation.

Contributing Factors: The fungus overwinters in dead leaves on the ground and in dormant buds. In the spring, spores are released to infect new growth. Splashing rain also helps spread spores.

Management Recommendations: Remove leaf debris and dead shoots from the trees during the winter. Avoid tight spacing and overhead irrigation. Preventative fungicide may be applied during budbreak in the spring and at regular intervals until leaves are fully developed (Elliott and Harmon 2014).

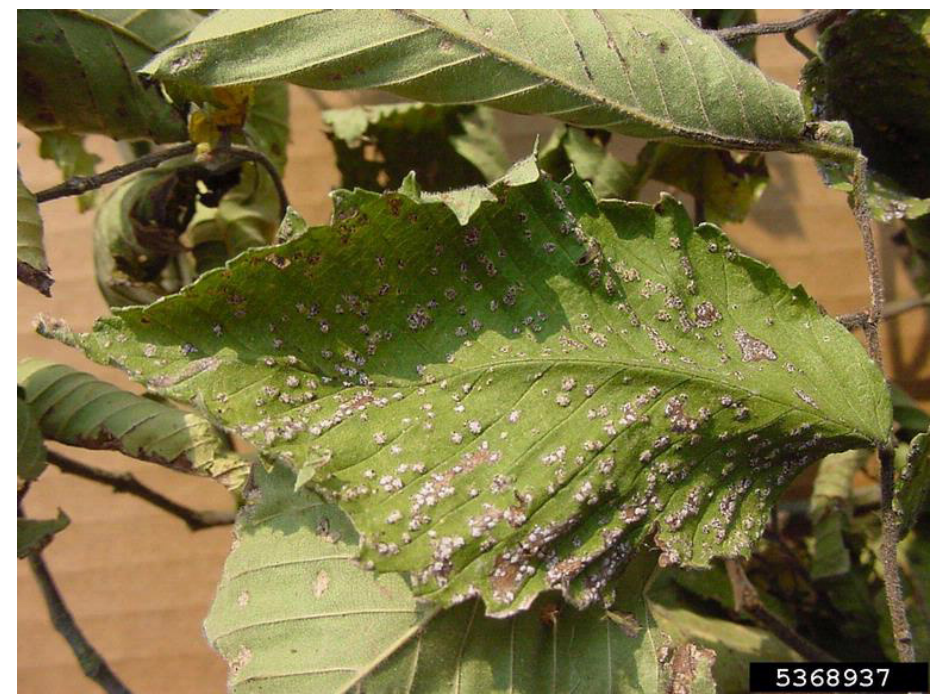

Figure 2. Leaves with cushion-like fungus caused by black elm spot. Credits: Paul Bachi, University of Kentucky Research and Education Center, Bugwood.org

\section{Powdery Mildew (Oidium spp.)}

Recognition: This fungal disease starts on young leaves as patchy, raised, blister-like areas that become covered with grayish-white powder. It may cause stunting, distortion of leaves, yellowing of leaves, premature leaf fall, and a general decline in plant growth.

Contributing Factors: Damp, shady conditions, overcrowded growth, poor air circulation, and overhead irrigation, particularly when irrigated at night.
Management Recommendations: Prune young trees for good air circulation, irrigate in the morning, prune out affected plant parts, and apply protective fungicides like copper sulfate at first sign of infection (Zhang, Palmateer and Pernezny 2017).

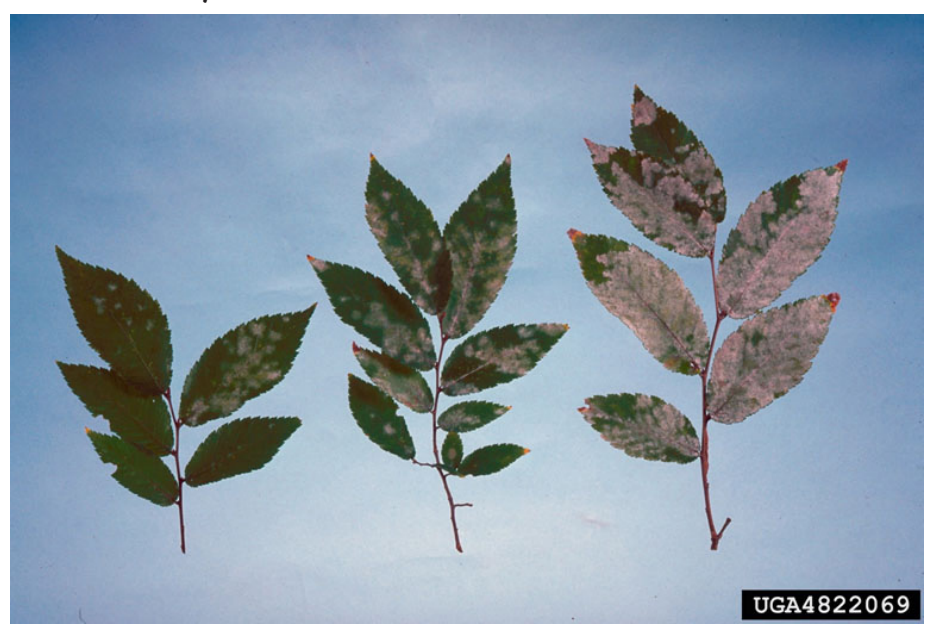

Figure 3. Various stages of powdery mildew infection on winged elm leaves.

Credits: Florida Department of Agriculture and Consumer Services, Bugwood.org

\section{Trunk Canker (Phytophthora sp., Botryosphaeria spp., Nectria sp.)}

Recognition: Cankers are areas of bark that are slightly sunken and water-soaked, with inner bark that has changed colors from a light tan to reddish-brown or brownish-black. Small twigs may be girdled and killed. There is usually a sharp division between healthy and diseased tissue as the canker dries, cracks, pulls away from the margin, and eventually falls off to reveal dead sapwood beneath. Small red-to-black fungal fruiting bodies may develop in the diseased tissue.

Contributing Factors: Often associated with nursery practices that injure bark tissue and on cold-damaged tissue.

Management Recommendations: Avoid bark injury. Remove all dead or diseased branches without leaving stubs or flush cuts. To prevent sunscald, protect the trunks of thin-barked elms from direct sunlight in late winter or if blown over. Chemical controls are generally not effective for prevention or control (Futch and Graham 2015).

\section{Wood-boring Pests}

Recognition: Several types of wood-boring pests, including beetles and moths, will attack Chinese elm. Small holes in the trunk or limbs with fine sawdust indicate the presence 


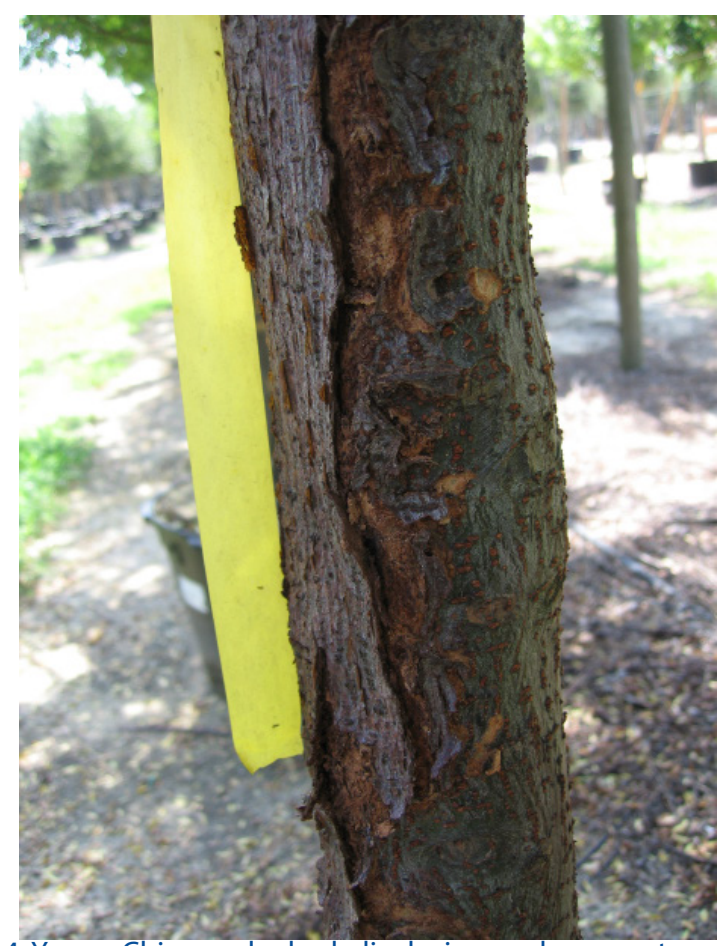

Figure 4. Young Chinese elm bark displaying canker symptoms. Credits: Juanita Popenoe, UF/IFAS

of beetles. The elm borer, Saperda tridentate (Oliver), is a beetle that feeds under the bark and girdles the trunk. The dogwood twig borer, Oberea tripunctata, is a moth that infests the twigs of elm. The larva tunnel through the terminal twigs and cut small holes to the outside from which they expel sawdust and feces. Infested twigs are girdled and killed by the female when she lays eggs. Infested twigs wilt and hang on the tree or drop to the ground (Gyeltshen and Hodges 2016).

Contributing Factors: Borers nearly always attack unhealthy or stressed plants or trees.

Management Recommendations: Natural enemies attack boring beetles, but do not reduce them to low levels in nursery stock. Typically, borers must be controlled with preventative insecticide treatments because, once the insects are under the bark, they are difficult to control. Pay particular attention to plants showing signs of stress, such as wilting, disease infection, or injury from equipment. Observe trees and woody plants for sap stains, holes in the bark, and blistered, peeling, or spongy bark areas, especially on plants that are stressed or have been subjected to trunk injury. Carry out all approved horticultural practices to promote plant vigor and health to minimize borer infestations.

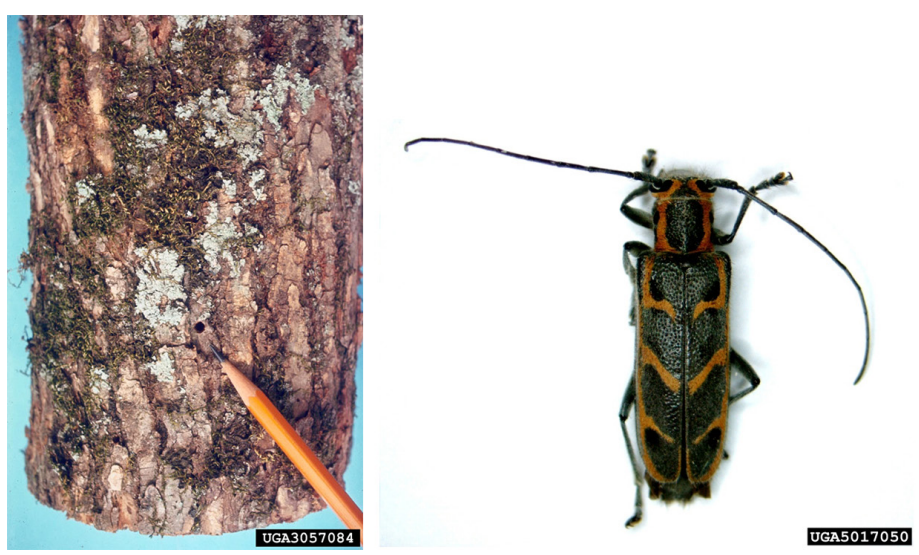

Figure 5. Left: Damage caused by elm borers. Right: Adult elm borer. Credits: James Solomon, USDA Forest Service, Bugwood.org (left); Pennsylvania Department of Conservation and Natural Resources $\mathbb{}$ Forestry, Bugwood.org (right)

\section{Eriophyid Mites (Phyllocoptes fructiphilus Keifer)}

Recognition: Eriophyid mites are microscopic, worm-like insects that are primarily spread by wind. They have only two pairs of legs. Infestations are usually identified by the distortion of leaves.

Contributing Factors: Eriophyid mites are host-specific and will not attack other plants. Infested plants nearby will act as a source of reinfestation.

Management Recommendations: Prune out and destroy infested twigs to control and remove the adults. If the infestation is severe, a dormant oil mixture or a miticide should be used.

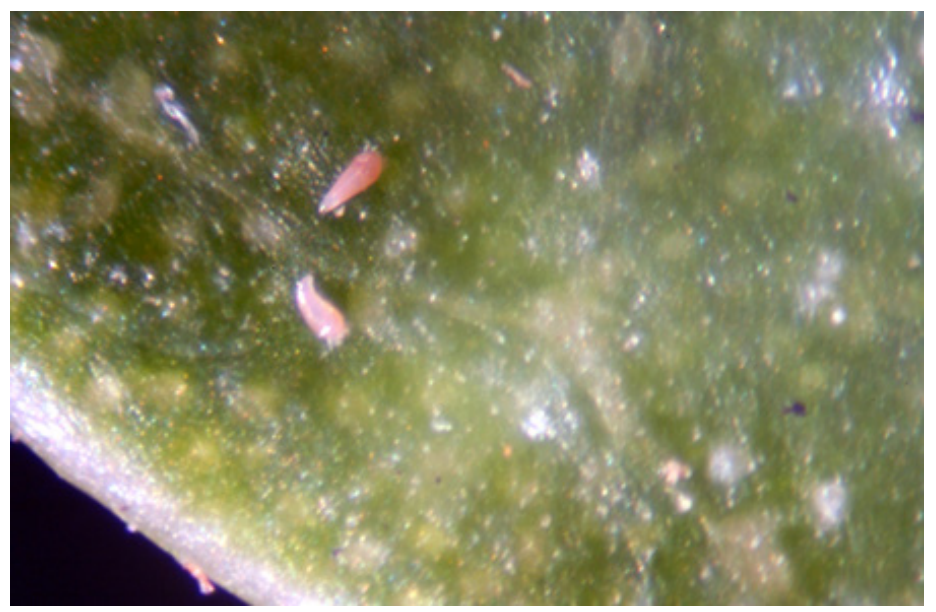

Figure 6. Eriophyid mites.

Credits: Lance Osborne, UF/IFAS 


\section{Elm Leaf Beetles}

Recognition: Leaf beetles skeletonize leaves and are general feeders during the summer months. Larger elm leaf beetles, Monocesta coryli (Say), are one of the largest species at 10 to 16 millimeters (approximately $1 / 2$ inch) in length. Their metallic blue and orange coloration also makes them easily recognizable. After spending three to four days feeding on leaf surfaces, larvae crawl down the tree and enter the ground where they remain until late winter or early spring. Adults are active from April to early August (Thomas 2014).

Contributing Factors: Be sure to remove all dead of dying branches, use proper irrigation techniques and avoid unnecessary pruning (Dreistadt and Lawson 2009).

Management Recommendations: There are some natural predators, but these are usually not sufficient to control beetles in the nursery.
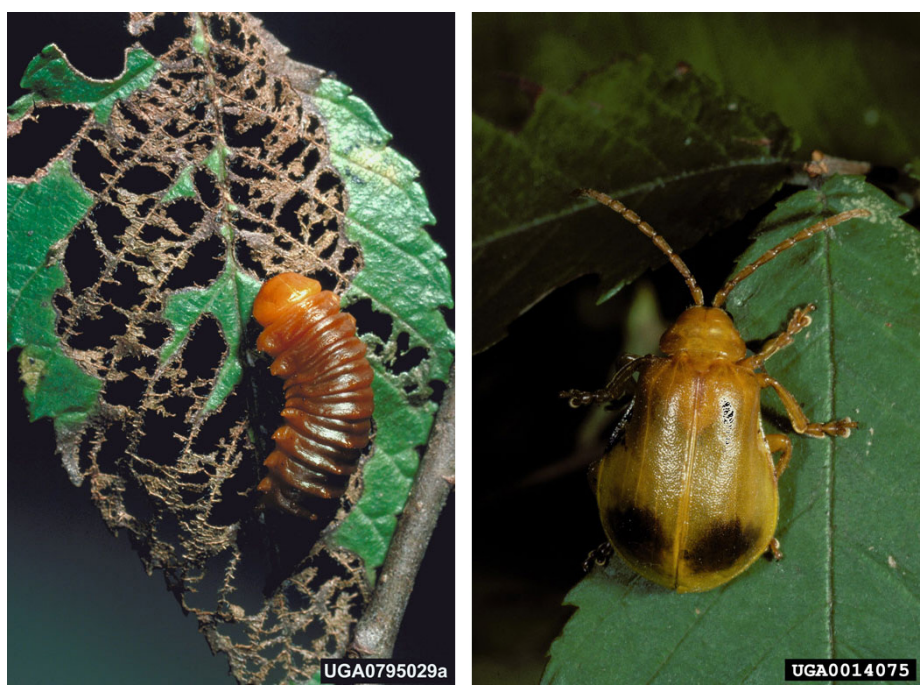

Figure 7. Larger elm leaf beetle larvae (left) and adult (right). Credits: Gerald J. Lenhard, Louisiana State Universty, Bugwood.org

\section{Scale}

Recognition: Scale can be recognized on the stems as bumps on the twigs. Live scales are moist when rubbed between your fingers, whereas dead scales are dry and crusty. These insects produce large volumes of a liquid waste called "honeydew" which gives leaves a shiny appearance. Sooty mold grows on the honeydew, causing heavily infested trees to be covered with sooty mold fungus.

Contributing Factors: More than 16 species of scale affect Chinese elm with European fruit lecanium being the most common. Control can be challenging and may need to be applied over several seasons. For beginners, get rid of scale insects by pruning and dispensing of infested twigs, branches, and leaves. When infestations are light, they may be removed by hand. Dabbing individual pests with neembased leaf shine or alcohol will kill off the scales. Additionally, commercially available beneficial insects, such as the ladybug (Coccinellidae) or green lacewings (Chrysopidae), can be used to control scale outbreaks.

Management Recommendations: Scale insects can be biologically controlled, as they are attacked by a variety of lady beetles, predatory mites, and small, parasitic wasps. The outer covering protects adult scales, so smothering oil sprays or systemic chemicals are required to control them. Contact sprays should be targeted to the crawler stage.

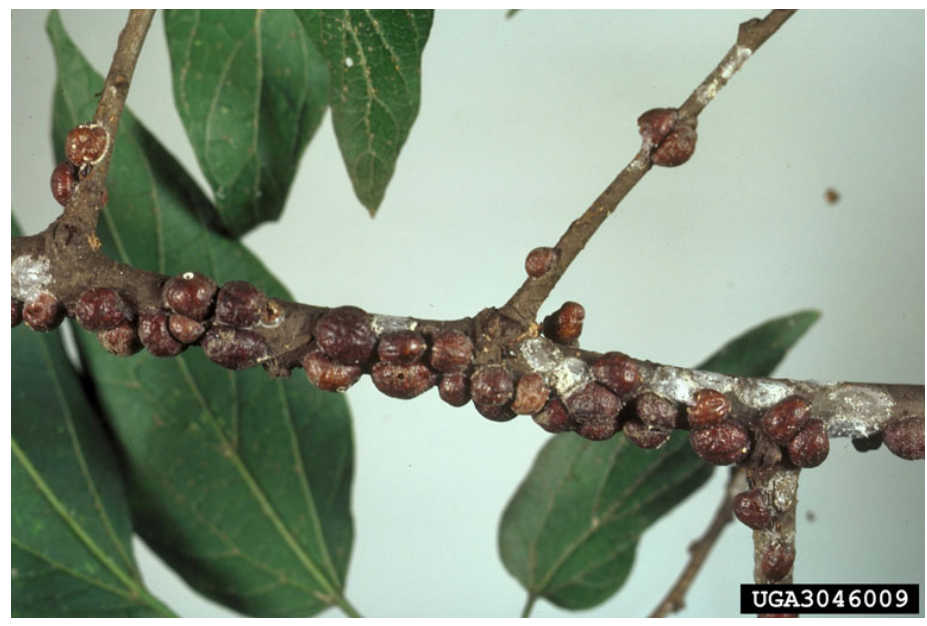

Figure 8. Lecanium scale infestation on sugarberry. Credits: James Solomon, USDA Forest Service, Bugwood.org.

\section{References}

Dreistadt, S. H. and A. B. Lawson. 2014. "Elm Leaf Beetle." http://ipm.ucanr.edu/PDF/PESTNOTES/pnelmleafbeetle. pdf

Elliott, M. L. and P. F. Harmon. 2014. Anthracnose. SSPLP-56. Gainesville: University of Florida Institute of Food and Agricultural Sciences. http://edis.ifas.ufl.edu/lh043

Futch, S. H. and J. H. Graham. 2015. Field Diagnosis and Management of Phytophthora Diseases. HS1015. Gainesville: University of Florida Institute of Food and Agricultural Sciences. http://edis.ifas.ufl.edu/hs261

Gilman, E. F. and Watson, D. G. 2014. Ulmus parvifolia: Chinese Elm. ENH809. Gainesville: University of Florida Institute of Food and Agricultural Sciences. http://edis.ifas. ufl.edu/st652 
Gyeltshen, J. and A. Hodges. 2016. "Dogwood borer, Synanthedon scitula (Harris).” http://entnemdept.ufl.edu/ creatures/trees/moths/dogwood_borer.htm

Hoy. M. 2013. "Eriophyid mite, Phyllocoptes fruitiphillus Keifer." http://entnemdept.ufl.edu/creatures/ORN/ph_fructiphilus.htm

Thomas, M. C. 2014. "Larger elm leaf beetle, Monocesta coryli." http://entnemdept.ufl.edu/creatures/trees/ le_leaf_beetle.htm

Townsend, L. 2005. "Lecanium scales." https://entomology. ca.uky.edu/ef430

Zhang, S., Palmateer, A. and Pernezny, K. 2017. Florida Plant Disease Management Guide: Beans. PDMG-V3-33. Gainesville: University of Florida Institute of Food and Agricultural Sciences. http://edis.ifas.ufl.edu/pg041 